\title{
Uvid u borbu nadbiskupa Desmonda Tutua protiv apartheida u Južnoj Africi
}

\author{
Alexander Kokobili \\ The Evangelical Theological Faculty, Charles University in Prague, Czech Republic \\ alexkokobili@yahoo.com \\ UDK: 329.42 \\ Pregledni članak \\ https://doi.org/10.32862/k1.13.1.5
}

\section{Sažetak}

Ovaj članak razmatra ulogu koju je nadbiskup Desmond Tutu odigrao u borbi protiv rasizma i socio-političke nejednakosti koju je promicao sustav apartheida u Južnoafričkoj Republici. Tutu je često u svojim govorima i javnozagovaračkim istupima osuđivao apartheid te promicao jednakost, pomirenje i miran suživot svih Južnoafrikanaca. Ideologija apartheida je crncima u Južnoj Africi otudila svako ljudsko dostojanstvo, što je u suprotnosti sa Svetim pismom u kojem piše: „Tako Bog stvori čovjeka na sliku svoju. Stvori ga na sliku Božju. Stvori ih kao muža i ženu" (Postanak 1,27). Unatoč tome je 1948. godine bjelačka Nacionalna južnoafrička stranka ozakonila apartheid kao politički sustav i pritom dobila podršku Nizozemske reformirane crkve bez obzira na to što se radilo o primjeni etike koja je protivna kršćanstvu. Apartheid je u Južnoj Africi usvojen s ciljem da se bijela manjina pozicionira kao viša društvena klasa, dok je crnačkoj većini bilo oduzeto niz prava $i$ povlastica. Desmond Tutu je bio jedan od malobrojnih kršćanskih vođa koji je u Africi utirao put crnačke teologije pri rušenju apartheida u Južnoj Africi. Tijekom njegove borbe protiv apartheida, Tutu nije poticao na nasilne prosvjede ili nerede, već je više pokušavao djelovati kroz svoje propovijedi $i$ poticati javnost na sudjelovanje u aktivnostima koje su promicale nacionalno jedinstvo, ljubav i jednakost svih Južnoafrikanaca.

Ključne riječi: apartheid, ljudska prava, jednakost, rasna nejednakost, ugnjetavanje. 


\section{Uvod}

Biskup emeritus Desmond Tutu (rođen 1931. godine u Južnoafričkoj Republici) se u razdoblju od 1982. do 1995. godine nametnuo kao vodeća ličnost u borbi protiv rasne nejednakosti u Južnoj Africi. Tutu je kao anglikanski biskup 1978. godine bio imenovan za glavnog tajnika Južnoafričkog vijeća crkava, a kasnije je 1984. godine dobio Nobelovu nagradu za mir. Istupao je javno protiv političkog sustava rasne segregacije apartheida i osuđivao bjelački orijentiranu Nizozemsku reformiranu crkvu u podržavanju neljudskih politika koje je provodila tadašnja afrička vlada. Sustav je apartheida 1948. godine uvela Nacionalna južnoafrička stranka kao dio svoga političkog programa rasne podjele stanovnika Južne Afrike na crne, obojene i bijele. Takav je politički obrazac favorizirao bijele Afrikanere na način da im je osiguravao više povlastica u smislu ostvarivanja socijalnih, vjerskih i političkih prava. Tako je vladajuća južnoafrička manjina podržavala rasizam, preferencijalno vlasništvo nad zemljom, plemensku segregaciju u pristupu javnim komunalnim i političkim službama te ograničavala sklapanje međurasnih brakova između crnih i bijelih Južnoafrikanaca. Tutu je vjerovao u jednakost svih ljudi i javno istupao protiv marginaliziranja crnaca u njihovoj vlastitoj zemlji od strane bjelačke manjine. Govorio je: „kad ustanovite da je apartheid pokušavao obmanuti ljude da vjeruju kako je ono što određuje vrijednost ljudskih bića zapravo nešto biološki potpuno irelevantno, poput boje kože ili etničke pripadnosti, a prije toga ste vidjeli da Sveto pismo kaže kako smo stvoreni na sliku Božju te da svaki od nas zapravo odražava samoga Boga. Bez obzira na to kakve su naše fizičke okolnosti, bez obzira na to koliko smo strašno lišeni svojih prava, to ne umanjuje našu intrinzičnu vrijednost“" (Tutu 1982, 46). Razdoblje apartheida u Južnoj Africi vremenski se podudara s vladavinom bijelačkih manjina u zemljama poput Namibije, Zimbabvea, Malavija, Bocvane itd. te s britanskim, francuskim, belgijskim i portugalskim kolonijalizmom u drugim dijelovima Afrike tijekom razdoblja od 1870-ih do 1970-ih.

\section{Ne želimo apartheid!}

Kršćanstvo se oduvijek smatralo religijom ljubavi, mira i pomirenja, u skladu s poslanjem Isusa Krista. Nažalost, apartheid je u Južnoj Africi podijelio Južnoafrikance, a Nizozemska reformirana crkva tim se problemom nije bavila zbog svoje povezanosti s vladajućom manjinom. Crkva je, naime, tada usvojila ideologiju „izabranog naroda“, pogrešno protumačivši zagovaranje Johna Calvina za državne izbore (Institucije 3.21, 1.1-4). Za razliku od Calvina, oni su sebe vidjeli kao dio bijele rase koju je Bog izabrao da budu nadmoćni nad svojim sunarodnjacima, crnim Južnoafrikancima. Identificirali su se kao carski kalvinisti u Južnoj 
Africi. Također, pogrešno su protumačili Calvinova prava ljudi da budu izabrani u političku službu. Crkva je smatrala da oni koji vladaju, pripadaju izabranom narodu koji je predodređen da bude nadmoćna ljudska rasa iznad drugih (Institucije 3.21, 1.1-4). To su uvjerenje tijekom nekoliko stoljeća bijeli Afrikaneri percipirali na različite načine. Tako su se, primjerice, „nizozemski Afrikaneri ranih 1870-ih nametnuli kao tumači afrikanerske baštine, kada su se Voortrekkeri počeli uspoređivati s Božjim izabranim ljudima. Tema, koja je tako snažno pridonijela razvoju apartheida među (izabranim) Afrikanerima, međutim, dala im je opravdanje da se odvoje od drugih ljudi i legitimno vladaju njima" (Ellingensen 1999, 267). Bila je to pozadina na temelju koje je Nizozemska reformirana crkva dala potporu vladajućoj rasnoj politici apartheida koja je bila u suprotnosti s ljudskim dostojanstvom, a koju je dosljedno provodila vladajuća nizozemska Nacionalna stranka. Tako je, primjerice, Daniel F. Malan, koji je tijekom razdoblja apartheida (1948. - 1954.) obnašao dužnost premijera, ustvrdio tijekom svog mandata: „Naša povijest je najveće remek-djelo stoljeća. Tvrdimo da nam je našu nacionalnu ulogu dodijelio sam arhitekt cijelog svemira. [Božji] cilj je bio stvaranje novoga naroda među narodima svijeta" (Moodie 1975). Malanova afrikanerska zabluda o rasnoj superiornosti bijele manjine u stvaranju novoga naroda je, naime, bila utemeljena na ideji nadmoći bjelačkoga Božjeg stvorenja nad crnačkom većinom. Štoviše, to je također dovelo do toga da europski imperijalizam poistovjeti Ubuntu kulturu s crnačkim dijelom južnoafričkog društva, potiskujući njihove kulturne vrijednosti i identitet. Za Tutua je apartheid stvorio polarizaciju između crnaca i bijelaca u južnoafričkom društvu, pri čemu su obje rase razvile međusobnu mržnju i prezir jedni prema drugima. Bilo je, dakle, potrebno obnoviti ljudsko dostojanstvo i tradicionalni društveni ubuntu život, koji je izvorno i činio temelje južnoafričkog društva.

Nadalje, sustav je apartheida ograničio južnoafričku politiku, zatvorivši je u rasizam i agresiju usmjerenu protiv crnaca. Takva je situacija dovela do uskraćivanja prava crnim Južnoafrikancima da koriste svoju zemlju, dok su bijeli Afrikaneri živjeli u obilju kao superiorna ljudska bića. Takva ideja o zatvorenom društvu promicala je grube povrede ljudskih prava i rasne nepravde, što je strano svakom demokratskome društvenom uređenju. Tako se, primjerice, Karl Popper pobunio protiv takvog društva zašto što dopušta ugnjetavanje, a potlačeni bi se zauzvrat mogli pobuniti. To je objasnio na sljedeći način: „Suvremeni totalitarizam je samo jedna epizoda unutar višegodišnjeg procesa pobune protiv slobode i razuma. Od prijašnjih se epizoda razlikuje, ne toliko po svojoj ideologiji koliko zbog činjenice da su njezini vođe uspjeli ostvariti jedan od najsmjelijih snova svojih prethodnika; pobunu protiv slobode pretvorili su u narodni pokret“ (Popper $1945,57)$. Tako se aparthejdska agenda nizozemske Nacionalističke stranke pozicionirala nasuprot slobodi i jednakosti crnaca iz Južne Afrike. Međutim, svako bi 
demokratsko društvo trebalo biti otvoreno za prihvaćanje svih rasa kao dijelova jednog Bogom danog naroda. Društvo treba brinuti za interese svih građana, bez obzira na njihovu rasu ili društveni status, a vladajući ne smiju marginalizirati prava na slobodu bilo koje skupine ljudi. Stoga, nedopustivo je da bilo koji politički režim povezan $s$ apartheidom, kao što su marksizam, fašizam, nacizam, totalitarizam, kolonijalizam itd., nameće svoje odrednice društvenog razvoja zbog svoje nemogućnosti da osigura ljudsko dostojanstvo i slobodu za svakoga.

\section{Tutuove etičke vrline jednakosti}

Tutuova su biblijska uvjerenja potaknula njegovu ideju evanđelja jednakosti svih rasa. Citirao je svetoga Pavla: "On je naš mir. Doista oboje sastavi u jedno, i razvali razdvojni zid svojim tijelom" (Efežanima 2,14). ${ }^{1}$ Tutu je vjerovao da rasno razdvajanje Božjeg naroda u Južnoj Africi zapravo predstavlja razdvojni zid koji je Isus Krist već srušio. Naglašavao je potrebu poštovanja ljudskog dostojanstva $\mathrm{i}$ prava crnaca u Južnoj Africi, govoreći: „,̌injenica da čak ni Crkva ne prakticira pomirenje, ukazuje na iznimno nepovoljno stanje stvari. To nije ništa drugo do proturječje u samoj naravi Crkve" (Tutu 1982, 18). To pokazuje licemjerje bjelačke Nizozemske reformirane crkve, posebice u njihovoj tvrdnji da se trude oko pomirenja u Južnoj Africi iako su na sinodi 1978. godine tvrdili da je apartheid u sukobu s Evanđeljem $(1982,18)$. Tutuova je borba također bila pod utjecajem pokreta za građanska prava Martina Luthera Kinga iz 1960-ih. Do 1986. godine Tutu je već dobio "nagradu za nenasilje" Martina Luthera Kinga ml. za svoja nastojanja u borbi protiv apartheida. Tutu je također bio izrazito nadahnut Kingovim pismom koje je 1963. godine napisao dok je služio kaznu u gradskom zatvoru u Birminghamu, Alabama, a 1982. godine je postao voditelj Južnoafričkog vijeća crkava (South African Council of Churches, SACC). Tvrdio je, međutim, da je ideologija rasnog oslobođenja zajednička odgovornost, kako Crkve tako i građanskih pokreta i stranih simpatizera. Tutu je vjerovao da je otkupljenje Južne Afrike dio Božjeg plana za oslobođenje zemlje od materijalističke ideologije vladajuće bjelačke manjine i njihove ugnjetavalačke tiranije. Objašnjavao je da je „Božja misija i svrha da svijet dovede do cjelovitosti, pravde, dobroga zdravlja, pravednosti, mira, sklada i pomirenja. To je ono što pripada Kraljevstvu Božjem, a mi smo Njegovi suradnici koji pomažu ostvariti sve što Bog želi u svome svemiru" (Tutu 1982, 26). Cilj je Crkve, dakle, osigurati trajno djelovanje Božje ljubavi u ljudskom društvu zato što Crkva služi kao Božje sredstvo ostvarenja pozitivne promjene u društvu. Crkva ne može ostati neutralna u odnosu na ne-

1 Svi su biblijski navodi prema Šarićevu prijevodu, 4. popravljeno izdanje. 
pravdu apartheida, već treba javno istupati protiv svake socio-političke nepravde i marginaliziranja Božjeg naroda.

Tutuova je teologija bila pod snažnim utjecajem moralnoga biblijskog uvjerenja o jednakosti svih ljudi („Nema tu više ni Židova ni Grka, nema više ni roba ni slobodnjaka, nema više ni muškog ni ženskog, jer ste svi jedno u Kristu Isusu” (Galaćanima 3,28). Po njemu su svi bijeli Afrikaneri trebali shvatiti da zemlja Južne Afrike izvorno pripada crncima unatoč tomu što su oni bili ti koji su doveli kršćanstvo iz Europe. Postoji, dakle, potreba da se Biblija i zemlja pomire, a sve s ciljem ostvarenja mirnog suživota. Tutu je govorio: „Kada je bijeli čovjek prvi put došao ovdje, imao je Bibliju, a mi smo imali zemlju. Onda nam je bijelac rekao da dođemo, kleknemo i molimo zajedno. Kleknuli smo i zatvorili oči, a kada smo ih opet otvorili, imali smo Bibliju i bijelac je imao zemlju" (Tutu and Battle 2009, 31). Želja bijelog Afrikanera za ekonomskom dominacijom dovela je do toga da je bjelačka manjina ugušila svoju pobožnu savjest u ime rasnog ugnjetavanja. Krivo razumijevanje, koje je imala bijelačka Nizozemska reformirana crkva u Južnoj Africi, bilo je u suprotnosti s Calvinovom reformacijom prava ljudi na slobodu. Također, biblijska je ideja ljubavi prema bližnjemu bila zanemarena zbog ljubavi prema moći i ugnjetavanju od strane apartheidske vlade i Nizozemske reformirane crkve. U znak priznanja bivši je južnoafrički predsjednik W. A. de Klerk kasnije potvrdio važnost Tutuove teologije o jednakosti svih ljudi, navodeći: „Pravda nije kukavičko odustajanje od težnji, prava i zahtjeva. Pravda je poslušnost. Pravda je život u skladu s pravilima ili Stvoriteljevim zakonom. Djelovati u skladu sa zakonom za vlastiti život znači izraziti svoj karakter i identitet. Tvoj vlastiti karakter je tvoj 'zakon života', a poslušnost njemu predstavlja ispunjenje pravde. Stoga, kažemo da je autogeni razvoj najbolja vježba za pravdu. Pravda je pluralitet i svatko tko napusti svoj položaj i tako ugrozi svoju budućnost, svatko tko zbog pogrešnog shvaćanja ljubavi ili pravde preuzme ispunjavanje tuđe zadaće, ne ostvaruje pravdu, već je zapravo nelojalan svome vlastitom pozivu i zakonu života“ (Tutu and Battle, 31) Ukidanje je apartheida novim ustavom Južne Afrike 1994. godine označilo kraj razdoblja izrazitog kršenja ljudskih prava i rasne nejednakosti. U vremenu nakon apartheida otvorile su se u društvu mogućnosti za razvoj građanske demokracije, a Nizozemska reformirana crkva i bijeli Afrikaneri su prilikom svjedočenja pred Komisijom za istinu i pomirenje 1995. godine bili prisljeni priznati svoju krivnju za kršenja ljudskih prava. Tutuova je ideja o ljudskim pravima bila most nade, u povezivanju naroda Afrike s vrijednostima rasne jednakosti i poštovanja ljudskih prava. Tutuova je teologija zagovarala pravednost za crnog čovjeka i zaštitu od kršenja svih rasnih prava od strane bjelaca, putem kompenzacije i djelovanja Odbora za rasno pomirenje. Njegovo je evanđelje pomirenja postalo svjetlo nade usred gorčine koja je vladala u društvu, a žrtve su trebale postati spremne oprostiti svojim apartheidskim tlačiteljima. Unatoč nezakonitim 
zatvaranjima i progonima crnih svećenika i građanskih aktivista, sva nastojanja koja su oko nacionalnog pomirenja poduzimali Tutu i Crne Crkve u Južnoj Africi ostala su dosljedna i uživala nedvojbenu podršku međunarodne zajednice.

\section{Tutuovo suđenje pred Eloffovom komisijom 1982. godine}

Tutuova upornost $\mathrm{u}$ borbi protiv apartheida dala je glas i hrabrost drugim crkvama da se zauzmu za ljudske slobode i jednakost u Južnoj Africi. Kao predsjedavajući Južnoafričkog vijeća crkava (SACC), Tutu je 1982. godine kritizirao apartheidski zakon afrikanerske vlade zbog promicanja rasizma, vjerske segregacije i društveno-političke nepravde. Afrikanerska nacionalna vlada ga je zbog njegova protivljenja apartheidu 1982. godine izvela na suđenje koje je vodila tzv. Eloffova komisija. Bilo je to zato što je afrikanerska vlada smatrala da su Tutu i crkve koje kritiziraju vladajući režim zapravo pobunjenici koji se protive građanskom poretku. Tijekom suđenja, Tutu je djelovanje vladajuće Nacionalne južnoafričke stranke i Nizozemske reformirane crkve osudio kao heretično, zlo i iskvareno. Rekao je: „Sudi nam se zbog toga što smo kršćani, i to od strane vlade koja za sebe tvrdi da je kršćanska. Moglo bi se shvatiti kao da nam se govori kako je uvredljivo biti kršćanin u Južnoj Africi“ (Tutu 1982, 4, 6). Tutu je Eloffovoj komisiji opisao apartheid kao sustav koji je „protiv Boga i koji promiče zlo i grijeh.“ Međutim, Savez reformiranih crkava u Južnoj Africi ga nije podržao, i to uglavnom zbog stava svojih bijelih afrikanerskih članova. Također, Tutu je 1982. godine pozdravio imenovanje ne-bjelačkog svećenika (Allana Boesaka) za predsjednika Svjetskog saveza reformiranih crkava zbog podržavanja božanskih vrijednosti Crkve u smislu zagovaranja jednakosti svih rasa (Tutu 1982, 4-9).

Nadalje, usporedio je zlo apartheida s nacizmom i komunizmom, naglasivši da je taj loš sustav uspio samo u promicanju nepravde i ugnjetavanja među crnačkom većinom u zemlji (Tutu 1982, 6). Stoga, Tutu je upozoravao vladu da ne slijedi zločince poput Adolfa Hitlera, cara Nerona itd., pošto su i vladajući samo obična ljudska bića i ne bi smjeli promicati tiraniju (Tutu 1982, 9). Također, založio se za slobodu Južnoafričkog vijeća crkava od svake političke manipulacije države te je tvrdio da se Crkva treba sloboditi svih oblika zla i nepravde koje donosi tiranija apartheida u zemlji (Tutu 1982, 9). Nadalje, za Tutua uskrsnuće Isusa Krista nad smrću predstavlja moć Crkve nad zlom apartheida u društvu. Također, to je u skladu s Biblijom: „Ako je Bog za nas, tko će protiv nas?“ (Rimljanima 8,31) (Tutu 1982, 9). Apartheid se uspoređivao sa zlom nacizma i komunizma u kojem je loš i zao sustav uspio samo promovirati nepravdu i djelovati protiv crnačkog stanovništva Južne Afrike. Tutu je pritom upozoravao vladu da ne slijede primjere poput Adolfa Hitlera, Benita Mussolinija, cara Nerona, Lenjina, Staljina itd. jer su vladajući samo obična ljudska bića i ne bi smjeli promicati tiraniju (Tutu 1982, 
9). Zalagao se za slobodu Južnoafričkog vijeća crkava od političkih manipulacija države i tvrdio da Crkva oslobođena od tiranije apartheida u zemlji mora nadvladati sve oblike zla i nepravde (Tutu 1982, 9). Na sličan je način Tutu govorio protiv heretičkih doktrina Nizozemske reformirane crkve, nazivajući ih zlima i iskvarenima. Ustvrdio je: „Sudi nam se zbog toga što smo kršćani, i to od strane vlade koja za sebe tvrdi da je kršćanska. Moglo bi se shvatiti kao da nam se govori kako je uvredljivo biti kršćanin u Južnoj Africi“ (Tutu, 1982, 4, 6). Tutu je tijekom saslušanja pred Eloffovom komisijom kritizirao zli i rasistički režim apartheida.

\section{Tutu i Povjerenstvo za istinu i pomirenje u Južnoj Africi 1995. godine}

Tutu i drugi građanski aktivisti sastali su se s Mandelom 1990. godine kako bi razgovarali o budućnosti Južne Afrike. Mendela je tada bio tek pušten iz zatvora nakon što je odslužio 27 godina zatvorske kazne. Tutu je otišao na taj sastanak zahvaljujući svemoćnom Bogu kroz himnu (Neka bude volja tvoja, o Gospode, Bože istine), a nakon toga je molio za narod Južne Afrike (Tutu 1982, 4-6). Taj je sastanak narodu dao ideju o tome koju bi zapravo svrhu trebala imati Tutuova komisija iz 1995. godine. Tutu je kasnije iste godine imenovan od strane predsjednika Mandele za predsjedavajućega Povjerenstva za istinu i pomirenje, koje se sastojalo od nekoliko predstavnika Anglikanske, Metodističke i Rimokatoličke Crkve, muslimana, hindusa, političara i predstavnika skupina za građanska prava koji su predstavljali bijele, obojene i crne Južnoafrikance (Tutu 1982, 4-6). Pro-aparthejdski orijentirana bjelačka Nizozemska reformirana crkva također je pozvana da sudjeluje u nacionalnom pomirenju. Težište je rada Tutuova povjerenstva bilo na otvaranju mogućnosti za ostvarenje pravde za potlačene te iscjeljenje osjećaja narušenog povjerenja, uz istodobnu reintegraciju tlačitelja u društvo ljubavi i poniznosti. Tutu se zalagao i za amnestiju bijelih tlačitelja, kako bi se svi tlačitelji suočili sa svojim greškama, a sve u svrhu postizanja mira. Na to se nije gledalo kao na znak slabosti crne rase, već kao na djelovanje u duhu pomirenja. Tutu je tijekom rada Povjerenstva ohrabrivao sve sudionike da uvide potrebu oprosta, baš kao što je Bog nama oprostio sve naše grijehe. Tutu je objašnjavao kako oprost predstavlja mandat Povjerenstva za istinu i pomirenje, navodeći da „naš ključni zadatak nije odmazda ili kazna, već djelovanje u duhu ubuntua u smislu liječenja razdora, ispravljanja neuravnoteženosti, ponovnog uspostavljanja prekinutih odnosa" (Tutu 1999). Poziv na pravdu je, dakle, bio prepoznat kao prioritet, kao svojevrsni način nadoknade onima koji su bili žrtve teških oblika kršenja ljudskih prava, kao što su, primjerice, bili mučenje, nezakonito zatvaranje, silovanje, ubojstvo itd. To znači da žrtve i njihove obitelji trebaju od Vlade dobiti potpunu kompenzaciju, i to na nekoliko načina kao što su financijska naknada, emocionalna ili mentalna rehabilitacija, vraćanje oduzete zemlje i ponovno okupljanje 
zajednica. Međutim, naglašavanje potrebe za pokajanjem i priznavanjem pogrešnog ponašanja i zločina od strane bjelačkih apartheidskih tlačitelja također je bilo prepoznato kao cilj rada Povjerenstva. Tutuovo je povjerenstvo ohrabrivalo sve apartheidske počinitelje da se pokaju i pažljivo ispričaju svojim žrtvama, a sve u duhu pomirenja i praštanja koje se propovijeda kroz ljubav Isusa Krista.

\section{Tutuova Ubuntu teologija}

Formulacija teološkog koncepta pomirenja biskupa Tutua je nadahnuta lokalnim sloganom koji dolazi iz popularne Zulu južnoafričke kulture, tzv. ubuntu. Tutuovo korištenje ubuntua afirmira afrički koncept zajednice koji naglašava integritet ljudskih bića stvorenih da žive na sliku Božju, čak i kada su usred sukoba (Tutu and Battle 2009, 5). Tutu u tom kontekstu ohrabruje potlačene da gledaju dalje od svojih iskustava iz prošlosti te da pritom oproste onima koji su ih prije tlačili i prihvate ih kao članove jedne Božje obitelji. To je zato što južnoafričko društvo ima svoj tradicionalni ubuntu način života u ljubavi i zajedništvu svih ljudi, bez obzira na etničku pripadnost. Tutuova Ubuntu teologija pomirenja je tako postala nadahnuće za prihvaćanje oprosta i ozdravljenja nakon povreda prouzročenih kršenjem ljudskih prava tijekom razdoblja apartheida. Tako je, primjerice, bivši predsjednik Nelson Mandela u svom intervjuu iz 2006. godine objasnio kakvu je važnost ubuntu imao za njega dok je odrastao u Južnoj Africi. Za njega ubuntu znači tolerancija, poštovanje, poniznost, opraštanje, zajedništvo, poštovanje, povjerenje, dijeljenje itd. pri čemu sve od nabrojanog predstavlja temeljne vrijednosti društva (Mandela 2006). Tutuova težnja za jedinstvom u Južnoj Africi proturječi ideologiji rasne segregacije koja je upisana u srca bijelih Južnoafrikanaca, koji smatraju da su superiorni u odnosu na svoje crne susjede. Objašnjavao je: „apartheid nije logičan (pošto) negira da su ljudska bića stvorena na Božju sliku; a to znači da teologija imago Dei bolje određuje čovječanstvo stoga što rasna ideologija neizbježno vodi u upotrebu moći, pri čemu tlačitelj pretpostavlja da je on taj koji određuje tko si ti zapravo" (Tutu and Battle 2009, 5). Ideja pomirenja između potlačenog i tlačitelja u društvu temelji se na načelu života u zajednici koji je u Južnoj Africi postojao i prije razdoblja aparthejdskog ugnjetavanja. Dakle, potlačeni ljudi moraju moći gledati dalje od želje za osvetom, a tlačitelj se treba promijeniti i odustati od svojih zlih djela te prihvatiti da je Bog dao zemlju na korištenje svim ljudima. No Tutuova ubuntu tradicija pomirenja također poziva Južnu Afriku da gleda s onu stranu rasne napetosti, tražeći život mirne koegzistencije. To znači da "možemo biti ljudi samo u zajedništvu, u koinonia, u uvjetima mira" (Tutu i Battle 2009, 5). Proizlazi, dakle, da je temeljna obmana apartheida u smislu vjerskog života u Južnoj Africi bila prikazati Boga kao autora rasne segregacije. Tako su bijeli Afrikaneri opisali apartheid kao kršćansko nače- 
lo temeljeno na pravdi, koje ima svrhu održati i zaštititi bijelu rasu kao zasebnu skupinu (Tutu and Battle 2009, 23). Na taj je način Daniel F. Malan, bivši premijer iz razdoblja apartheida (1948. - 1954.) u Južnoj Africi, opravdavao nizozemski sustav rasne segregacije od strane Vlade, navodeći: „Naša je povijest najveće remek-djelo stoljeća. Tvrdimo da nam je našu nacionalnu ulogu dodijelio sam arhitekt cijelog svemira. [Božji] cilj je bio stvaranje novoga naroda među narodima svijeta" (Tutu and Battle 2009, 23). Malanovo afrikanersko krivo poimanje o rasnoj superiornosti bijele manjine imalo je za cilj stvoriti nov narod temeljem bjelačke dominacije Božjeg stvorenja nad crnačkom većinom. Za Tutua je apartheid stvorio polarizaciju između crnaca i bijelaca u južnoafričkom društvu, pri čemu su obje rase razvile međusobnu mržnju i prezir jedni prema drugima. Nadalje, Tutu je svoje uvjerenje objašnjavao drugačije od bivšeg premijera apartheida Daniela Malana, govoreći da „osim duboke povrijeđenosti koju je politika apartheida nanijela svim svojim žrtvama, kao što je primjerice vrijeđanje njihova ljudskog dostojanstva; postoji također i agonija apartheida, bantustanska politika koja teži pretvoriti crnce u strance u njihovoj vlastitoj domovini, tako da crnačka Južna Afrika prestane postojati“ (Tutu i Battle 2009, 26). Ideja apartheida se također ugnjetavalački odnosila prema lokalnoj kulturi i osjećaju zajedništva, s ciljem potkopavanja ljudskog dostojanstva crnih Južnoafrikanaca. U tom je smislu ponovno podizanje ubuntu svijesti bilo usmjereno na vraćanje izvornog načina života crnačkih zajednica.

Za Tutua, bijeli Afrikaneri moraju shvatiti da zemlja Južne Afrike izvorno pripada crncima unatoč tome da su oni bili ti koji su doveli kršćanstvo iz Europe. Može se reći da je želja bijelih Afrikanera za ekonomskom dominacijom rezultirala time da je bijela manjina ugušila vlastitu pobožnu savjest pravilnog poimanja rasnog ugnjetavanja. Ipak, crnačka većina danas razumije da im je ista ta Biblija, koju su primili od bijelaca, otvorila oči za deset Božjih zapovijedi; koje se usredotočuju na ljubav prema sebi i bližnjemu. Tako je, dakle, ideja ljubavi bila zanemarivana od strane Vlade apartheida i bijelačke Nizozemske reformirane crkve zbog ljubavi prema moći i ugnjetavanju. Međutim, Tutu je pozivao na pomirenje uz pomoć kojega se obnavljaju mogućnosti za oprost i jednakost, kako za crnce tako i za bijelce, kao pripadnike jednoga naroda koji je stvoren od Boga da bi zajedno uživao sva blaga svoje zemlje. Nevidljivi je zid apartheida konačno 1994. godine uklonjen iz zakonodavstva Južne Afrike, baš kao što je i Berlinski zid pao 1989. godine. Tako je Tutuova kampanja pomogla svim Južnoafrikancima koji su tražili zajedničko pomirenje i budućnost za svakoga, a ne samo onima koji su se zalagali za odabrane rasne ili plemenske vladine politike. Bivši je afrikanerski predsjednik W. A. de Klerk, koji je ukinuo rasne zakone i potvrdio Tutuovu teologiju pomirenja, rekao: „Pravda nije kukavičko odustajanje od težnji, prava i zahtjeva. Pravda je poslušnost. Pravda je život u skladu s pravilima ili Stvoriteljevim zako- 
nom. Djelovati u skladu sa zakonom za vlastiti život znači izraziti svoj karakter i identitet. Tvoj je vlastiti karakter stoga tvoj 'zakon života', a poslušnost njemu predstavlja ispunjenje pravde. Stoga, kažemo da je autogeni razvoj najbolja vježba za pravdu. Pravda je pluralitet i svatko tko napusti svoj položaj i tako ugrozi svoju budućnost, svatko tko zbog pogrešnog shvaćanja ljubavi ili pravde preuzme ispunjavanje tuđe zadaće, ne ostvaruje pravdu, već je zapravo nelojalan vlastitu pozivu i zakonu života" (Tutu and Battle 24). Iz toga razloga zapravo bijeli Afrikaneri 1990. godine i nisu imali drugog izbora nego prihvatiti prijedlog pomirenja i priznati krivnju za svoje zločine nad crnačkom većinom. U tom trenutku borba nije bila za rasnu ili etničku nadmoć, već za priznanje jednakosti ljudskih prava i sloboda. Crni su Južnoafrikanci također prihvatili postavku da im je Bog dao njihovu zemlju koja sada, međutim, pripada svim građanima Republike, što uključuje njihove bijele susjede. Po Tutuu se ubuntu teologija pomirenja Južne Afrike može povezati s vrlinama Isusa Krista kao dobrog pastira, koji je dao svoj život da bi se čovječanstvo s njim izmirilo u pokajanju. Objašnjavao je: „Isus kaže da je na nebu veća radost kada se pokaje jedan grešnik nego zbog njih devedeset i devet kojima ne treba pokajanje. Kršćani su ograničeni imperativima ovog Evanđelja, radosne vijesti Boga, koji je usprkos uobičajenim standardima koji se primjenjuju u svijetu, pristran prema grešnicima. Sve ono što jesmo i ono što imamo, čak i naše spasenje, predstavlja dar, i to ne dar koji trebamo zaslužiti, već dar koji trebamo slobodno primiti. Bog ne odustaje ni od koga jer nas je oduvijek ljubio. Bog nas i sada ljubi i uvijek će nas ljubiti. Sve nas, bili mi dobri ili loši, uvijek i zauvijek. Oni koji misle da to otvara vrata moralnoj površnosti, očito nikada nisu bili zaljubljeni jer je ljubav puno zahtjevnija od zakona“" (Tutu 1999, 74-75). To je razlog što ubuntu ideologija pomirenja stavlja najveću važnost na poniznost, mir i zajedništvo umjesto na osvetu protiv počinitelja apartheidskih nepravdi.

\section{Sažetak}

Ovaj članak razmatra Tutuovu ulogu u borbi protiv apartheida u Južnoj Africi i njegov kasniji društveni utjecaj. Tutuov je utjecaj još uvijek relevantan u zagovaranju mira, ljubavi i pomirenja na afričkom kontinentu. Primjerice, njegova uloga predsjedavajućeg Konferencije svih afričkih crkava (All Africa Conference of Churches, AACC) osigurala mu je priliku da 1994. godine posjeti nekoliko afričkih zemalja u svrhu provedbe nacionalnog pomirenja. Tutu i njegova radna skupina uglavnom su posjećivali zemlje koje su pretrpjele teška kršenja ljudskih prava, a sve s ciljem pomaganja ozdravljenja u zemlji (Tutu 1999, 206-207). To je također bilo značajno za zemlju kao što je Nigerija, koja je godinama trpjela vojnu diktaturu i kršenje ljudskih prava, prije nego što je 1999. godine postala demokratska država. Kao rezultat tih napora, nigerijska je vlada 1999. godine 
osnovala Povjerenstvo za istraživanje kršenja ljudskih prava i imenovala katoličkog biskupa, po imenu Mathew Kukah, za tajnika Povjerenstva. Ostale zemlje, kao što su Liberija i Angola, koje su godinama trpjele užase građanskog rata, također su formirale slična povjerenstva. Tutuovo je djelovanje također potaknulo stvaranje demokratskih vlada u onim dijelovima Afrike koji su prije bili pod vojnom diktaturom.

Nadalje, unatoč Tutuovu zagovaranju, kašnjenje u provedbi izvješća koja su sastavila Povjerenstva za mir i pomirenje u zemljama kao što su Sudan, Zimbabve, Srednjoafrička Republika itd., dovelo je do kršenja Povelje o ljudskim pravima Ujedinjenih naroda iz 1948. godine. Također, Crkva ne smije posustati u svojim naporima propovijedanja Božje ljubavi, kao što se to stalno naglašava Tutuovom porukom jednakosti i pomirenja. U tom je smislu stalno otvoren poziv svim ljudima da prihvate dijalog usred sukoba i da cijene napore kršćana u ostvarivanju mira. Tutuu je to omogućilo da dobije poziv predsjednika Pasteura Bizimungua iz Ruande da se obrati narodu Ruande nakon genocida koji su pripadnici plemena Hutu počinili 1994. godine protiv pripadnika plemena Tutsi. Tutuova neprestana podrška miru također se nastavlja i tijekom ovoga stoljeća. Tutu nam objašnjava: „Mir je moguć, posebice ako današnji protivnici mogu zamisliti sebe kako postaju prijatelji i počinju djelovati na način koji će promicati razvoj takvog prijateljstva u stvarnosti. Bilo bi divno kada bi oni tijekom pregovaranja pokušali pronaći načine zadovoljavanja potreba jednih i drugih. Spremnost na ustupke predstavlja znak snage, a ne slabosti“ (Tutu 1999, 226). To znači da se Crkva uvijek treba usredotočiti na pozitivne mogućnosti u ostvarivanju mira, kao nade čovječanstva u spašavanju zemlje od daljnjeg uništenja Božjeg naroda. Crkva bi uvijek trebala prihvatiti svoje odgovornosti i biti dio procesa pomirenja protiv diskriminacije ljudi na afričkom kontinentu. Konačno, Tutuov laboratorij pomirenja u društvu nije mjesto pukog društvenoga eksperimenta, već jasna poruka Isusa Krista koja donosi slobodu, ljubav i nadu svim građanima na ovoj zemlji.

\section{Literatura}

A history of Apartheid in South Africa. 2016. http://www.sahistory.org.za/article/ history-apartheid-south-africa (pristupljeno 19. 11.2018.)

Calvin, John. 2011. The Institutes of Christian Religion (translated by Henry Beveridge). Seattle, Pacific Publishing Studio.

Dunbar, Moodie T. 1975. The Rise of Afrikanerdum: Apartheid and the Afrikaner Civil Religion. Regents University of California Press.

Ellingesen, Mark. 1999. Reclaiming our Roots: Martin Luther to Martin Luther King Jr. (Vol 2). Trinity Press. 
Mandela, Nelson. Experience ubuntu.ogv. author:@canonical, Ltd. Date: 24 May 2006.

Popper, Karl. 1945. The Open Society and its Enemies. Vol 2 The tide of high prophecy: Hegel, Marx and the Aftermath. George Routledge \& Sons, LTD. London.

Tutu, Desmond. 1982. On Trial (1 September 1982 + South Africa + Government puts Council of Churches on trial + Tutu before Eloff Commission).

Tutu, Desmond. 1999. No Future without Forgiveness. Random House South Africa (Pty) Limited.

Tutu, Desmond i Michael Battle. 2009. Reconciliation: the Ubuntu theology of Desmond Tutu. The Pilgrim Press. Cleveland-Ohio.

s engleskog prevela Dalia Matijević

Alexander Kokobili

\title{
An Insight on Archbishop Desmond Tutu's Struggle Against Apartheid in South Africa
}

\begin{abstract}
This article focuses of Archbishop Desmond Tutu's role against the apartheid system of racism and socio-political inequality in the Republic of South Africa. Tutu often denounced apartheid in his speeches and public advocacy promoting equality, reconciliation, and peaceful coexistence of all South Africans. The ideology of apartheid robbed the black race in South Africa of their human dignity which contradicts the Holy Bible which states, "So God created man in His own image; in the image of God He created him; male and female He created them" (Genesis 1:27). Despite this, the white National Party of South Africa in 1948 legitimized apartheid as a political system and gained support from the Dutch Reformed Church despite its anti-Christian ethics. Apartheid was adopted to place the white minority in the upper class, while the black majority was left with fewer rights and fewer privileges in South Africa. Desmond Tutu was one of the few Christian leaders in Africa who championed the course for black theology in the demolition of apartheid in South Africa. Tutu's attitude during the apartheid struggle was not by violent protest or riots but rather through his sermons and public participation in activities clamoring for national unity, love, and equality of all South Africans.
\end{abstract}

